\title{
The Review on Insolvency of Sharia Insurance Company from the Perspective of Islamic Economic Law in Indonesia (Case Study on Bankruptcy Decision of Asuransi Syariah Mubarakahco. Ltd Number 1016 K/Pdt.Sus-Bankrupt/2016)
}

\section{Gemala Dewi}

\section{Abstract}

Humans are created as social beings to help one another between human beings. This concept is carried out by the insurance based on sharia principles. The principles in general is the concept of mutual help where a group of people help each other, mutually

Corresponding Author:

Gemala Dewi

gemalafillah@gmail.com

Received: 18 January 2019

Accepted: 24 March 2019

Published: 31 March 2019

Publishing services provided by

Knowledge E

(c) Gemala Dewi. This article is distributed under the terms of the Creative Commons

Attribution License, which permits unrestricted use and redistribution provided that the original author and source are credited.

Selection and Peer-review under the responsibility of the First ELEHIC Conference Committee. guarantee, and work together, with each way out of tabarru funds. Insurance companies generally still have some very typical problems, namely insurance technical problems and unexpected factors that greatly affect the business. This problems might end up in the bankruptcy as it is happened as PT Asuransi Syariah Mubarakah (The ASM Co, Ltd) which issettled by verdict of The Commercial Court judge Number 1016 K/Pdt.SusBankrupt/2016. The purpose of this research is to know the difference between Insolvency or Bankruptcy of conventional financial institution and Sharia Financial institution in the court decision in daily application; to know is there any relevance of the Religious Court in responding to Bankruptcy Cases instead of Commercial Court in Indonesian legal system. With no clarity on the position of the Bankruptcy Case (Taflis) in the authority of the Religious Courts, to find out what matters need to be prepared in the perspective of Islamic economoc law application. The result shows there are main differences between the characteristics of the financial institutions, however the court decision shows no deference according to the law order. The Supreme Court Judge consider the bankruptcy so as to provide legal certainty to the creditors of The ASM Co.Ltd. while the core of the contract itself did not in its consideration. That is why the conclusion needs the eligibility of Re ligious Court to decide the sharia insurance insolvency dispute settlements.

Keywords: Insolvency, Sharia Insurance, Religious Court, Islamic Economic law

\section{S OPEN ACCESS}




\section{Introduction}

According to Law no. 3 of 2006 on Amendment to Law no. 7 of 1989 on Religious Courts, the authority to try Islamic economic matters, especially in the field of banking and insurance have become the authority of the Religious Courts [1]. The authority of the Religious Courts has undergone extension, which originally only covers certain civil service cases that are "family case", Now has wider authorities covering 9 (nine) areas, namely: marriage, (b) inheritance, (c) will, (d) grant, (e) wakaf, (f) zakat, (g) infaq, (h) Sadaqah and (i) sharia economy. The extension of the jurisdiction of the judiciary has led to an extension of the notion of Islamic "Principle of Personality", which used to include only the "person" as a "natural person", now also encompassing the definition of "person" in the legal sense. Elucidation of Article I Number 37 on Changes in Ps. 49 of Law 7/89, mentions:

"The meaning of: "between persons of Islam" includes any person or legal entity who voluntarily submits to Islamic law on matters under the jurisdiction of the religious court in accordance with the provisions of this Article"

Based on the above provisions, for the dispute over sharia banking and insurance, as long as the contract between parties is of course based on shariah contract law provisions, it is not necessary to question whether the authority of the Religious Court or the District Court. Because of these provisions, all Islamic economic matters, whether between individuals or legal entities have become the authority of the Religious Courts.

At present the increasingly complex economic problems in Indonesia can be seen from the many economic cases involving various parties to resolve the cases. Some cases that are currently enough to attract the attention of economic actors is a case of bankruptcy. Several cases of bankruptcy that have been handled by commercial court as authorized institution to adjudicate bankruptcy cases, one of them is the bankruptcy case of PT Asuransi Syariah Mubarakah (The ASM Co, Ltd). From that it emerged some formulation of the problems that are: How the fundamental difference branch of Bankruptcy case of conventional financial institution (LKK) and Sharia Financial institution?; How is the relevance of the Religious Court in responding to Bankruptcy Cases?; With no clarity on the position of the Bankruptcy Case (Taflis) in the authority of the Religious Courts, what matters need to be prepared?

From the above facts it becomes a challenge for Religious Court judges to be more vigilant and deepen the knowledge in shariah contract law because of the complexity of shariah economic lawsuit which becomes its authority covering 11 areas, including banking, insurance, capital market and sharia business which is constantly evolving. If 
there are no detailed guidelines, then for Religious Court judges who, prior to 2006, are only family courts, must now be more assertive in deciding the contradictory cases of parties involving billions of rupiah value and will affect the livelihood of many people.

The purpose of this research is to know the process of insolvency of an insurance company based on sharia principles viewed from applicable law in Indonesia, to review the legal basis of the Supreme Court Judge of the Republic of Indonesia in bankrupting an insurance company based on sharia principles, and to find out the possibility of insurer sharia bankruptcy from the point of view of Islamic Economic Law in case of failure to pay claims to be brought to Religious court authority and what to be prepared.

\section{Methodology}

The research method used is a Normative legal research or library research which is a study that examines the study of documents, namely using various secondary data such as legislation, court decisions, legal theory, and can be the opinions of scholars. This type of normative research uses qualitative analysis by explaining the data. Research methods in this study include the following:

\subsection{Form of research}

Based on the form, this research is included in prescriptive research that is research that is intended to solve the problem or find a way out in addressing the case of bankruptcy against The ASM Co, Ltdas an insurance company as the case study for finding the relevance of Religious Court authority in solving the sharia insurance insolvency case.

\subsection{Data type}

The data used in this study are primary and secondary data, data obtained directly and in the form of data not obtained directly from the field but through literature materials consisting of primary, secondary, and tertiary legal materials. Primary legal materials in the form of legislation, especially from Law no. No. 37 of 2004 concerning Bankruptcy and Postponement of Obligation of Debt Payment (UUK 2004), and The decision on insolvency of Sharia Insurance The ASM Co. Ltd was upheld by Decision of Cassation in the case Number 1016 K / Pdt.Sus-Bankrupt / 2016. Secondary legal materials in the form of books, theses, papers, journals, articles, newspapers, and the internet which has 
the contain regarding the topics. Tertiary legal materials are dictionaries. In addition to secondary data, primary data is used where data is obtained from informants.

\section{Results and Discussion}

\subsection{Operational concept of Sharia insurance}

Some Muslims consider insurance against qodlo and qadar as predetermined destiny [2]. The risk of death, accidents, and natural disasters is one of destiny that cannot be rejected by a creature called human. It's just not the function of insurance to prevent the fate that will come to humans, but anticipate what things will cause harm from the existence of these risks that become the function of insurance as one way of preventive planning that can be taken by someone to face the future [3]. This is confirmed in the QS. Yusuf (12): 46-49 which describes human effort to establish a system of protection against the bad possibilities of the future by setting aside some of the crops during the fertile first seven years as food substitutes for the next seven difficult years.

Sharia insurance is an alternative system, exactly a substitute for conventional insurance that implements a system or contract of exchange that is not in line with Islamic Shari'a. The concept of insurance based on sharia principles is the concept of mutual help where a group of people help each other, mutually guarantee, and work together, by each way out of tabarru funds. Tabarru in the dictionary al-Munawwir interpreted with alms or kind of charity [4]. In sharia insurance tabarru'fund is very different from premium payment in conventional insurance system. Unlike the case with conventional insurance which the insurer ie the insurance company has an obligation arising as a legal consequence of the insurance agreement made with the insured is to pay insurance money in case of an insured event [5]. However, in sharia insurance, the insurance company is not as the insurer, but as the holder of the mandate which collects Tabarru 'funds intended to help people among the affected people [6]. So in this case the buyer does not buy the policy, and the absence of transfer of ownership of funds, but the pooling of funds [7]. Because of this concept is Takaful insurance agreement is called as takaful concept [8]. Subject to the deposit of funds by a sharia insurance company whose nature is management, it becomes attractive when it is associated with bankruptcy where bankruptcy can occur when the debtor has at least two creditors, the debtor does not pay off at least one debt to one of his creditors, as well as the debt has fallen and has been billed. Conditions on the necessity of two or more creditors are known as concursus creditorium [9]. In a Takaful company when the company does not pay the customer's claim then it is not 
a debt because the company is only a fund manager, it is not proper for bankruptcy in the Takaful company. Based on the above, it is necessary to examine the validity of the insolvency of sharia insurance companies due to not paying claims to customers and the authority of commercial courts in solving the case of Takaful insurance.

\subsection{Sharia insurance company insolvency}

\subsubsection{The concept of bankruptcy and insurance}

Bankruptcy is a condition in which the debtor is unable to make payments to the debts of his creditors. The situation is not able to pay normally due to the difficult financial condition (financial distress) of the debtor business that has been declining. While the bankruptcy is a court decision that resulted in general confiscation of all the wealth of the debtor bankrupt, either existing or that will exist in the future [10]. From the provision of Article 2 paragraph (1) of UUK-PKPU, it can be concluded that the request for bankruptcy statement against a debtor may only be filed if the following conditions are met [11]:

1. The debtor against whom the petition is filed must have at least two creditors; or in other words must have more than one creditor

2. The debtor does not pay at least one debt to one of his creditors

3. Unpaid debts have fallen and can be billed (due and payable

Bankruptcy is a commercial solution to get out of debtor debt problems that squeeze a debtor, where the debtor is no longer able to pay the debts to his creditors. So if the inability to pay the matured obligation is recognized by the debtor, then the step to apply for the determination of the bankruptcy status of itself (voluntary petition for self bankcruptcy) becomes a possible step, or the determination of the bankruptcy status by the court against the debtor if later found evidence that the debtor is indeed no longer able to pay the debt that has been matured and can be involuntary (involuntary petition for bankruptcy). Bankruptcy is also a further implementation of the principle of creditorium parity and the principle of pari passu prorate parte in the legal regime of wealth (vermogensrecht). The principle of creditorium parity means that all debtors' assets either in the form of movable or immovable goods or assets now owned by the debtor and goods in the future will be owned by the debtors are bound to the settlement of the debtor's obligations. While the principle of pari passu prorate parte means that the property is a collateral for the creditors and the proceeds should be distributed 
proportionally between them, except where there are creditor who according to the law must take precedence in receiving the payment of the bill.

Insurance can be defined as a risk coverage [12]. Risk coverage does not merely endure something that could happen to a person in the event of a loss to the goods or services even to the soul of that person, but also to bear the fear of recovery from the risk of loss occurring. So in this case the insurance not only provides protection, but also a sense of security that arises as a logical consequence of giving replacement and recovery of a person's losses $[13,14]$.

According to the provisions of Article 2 paragraph (5) of The Law on Bankruptcy and Suspension of Payment Obligationson (UUK-PKPU), in the event that the debtor is an insurance company, reinsurance company, pension fund or State-Owned Enterprises engaged in public interest, a petition for bankruptcy statement may only be filed by the Minister of Finance. According to Article 2 paragraph (5) UUK-PKPU mentioned that:

"Referred to as" Insurance Company "is Life Insurance Company and Insurance Company against Losses. Insurance Companies and Reinsurance Companies are Insurance Companies and Reinsurance Companies as referred to in the Law regulating the Insurance Business. The authority to apply for a bankruptcy statement to an Insurance or Reinsurance Company is fully available to the Minister of Finance. This provision is necessary to build a level of public confidence in the Insurance Company or Reinsurance Company as a risk management institution as well as a public fund management institution that has a strategic position in development and economic life.

Although it is not explicitly mentioned in the OJK Law nor the OJK rules that the authority to apply for insolvency for Insurance Company has been transferred from the Minister of Finance to OJK, nor has there been any revision in The Law on Bankruptcy and Suspension of Payment Obligationson (UUK and PKPU) regarding the transfer of authority to file a bankruptcy request from the Minister of Finance to OJK. However, in its development on October 17, 2014, the Insurance Business Law was revised into an Insurance Law. In Chapter $X$ of the Insurance Law of Article 42-Article 52 is stipulated on the Dissolution, Liquidation, and Insolvency of Insurance Companies which is the authority of OJK. For the authority of OJK to file a bankruptcy against an Insurance Company shall be regulated in Article 50 of the Insurance Law, which states that:

1. Application for bankruptcy statement against Insurance Company, Sharia Insurance Company, Reinsurance Company, or Sharia Reinsurance Company pursuant to this Law may only be submitted by the Financial Services Authority. 
2. Procedures and requirements for the application of bankruptcy declaration against Insurance Companies, Sharia Insurance Companies, Reinsurance Companies or Sharia Reinsurance Companies as referred to in paragraph (1) shall be conducted in accordance with the provisions of laws and regulations.

3. The request for declaration of insolvency against an Insurance Company, a Sharia Insurance Company, a Reinsurance Company, or a Sharia Reinsurance Company as referred to in paragraph (1) shall not be filed in order to execute a court decision.

Article 51 of the OJK Law states that:

1. The creditor submits an application to the Financial Services Authority to file an application for a bankruptcy declaration to the commercial court.

2. The Financial Services Authority approves or rejects the application submitted by the creditor as referred to in paragraph (1) no later than 30 (thirty) days after receipt of the complete application

3. In the event that the Financial Services Authority rejects the application submitted by the creditor as referred to in paragraph (2), the refusal shall be made in writing with the reasons thereof.

4. Further provisions concerning the procedure and requirements of the application and creditors as referred to in paragraph (1), paragraph (2) and paragraph (3) shall be stipulated in the Regulation of the Financial Services Authority.

From the stipulations above, can be seen that in Indonesia, bankruptcy on an insurance company only can be sued by The Financial Services Authority (OJK). It is OJK's authority to request a bankruptcy statement on Insurance cases.

In the general elucidation of the OJK Law it is stated that: "The Financial Services Authority (OJK) performs its duties and authorities on the basis of the following principles":

1. Principle of independence, which is independent in decision making and execution of function, duties and authority of OJK, in accordance with prevailing laws and regulations;

2. The principle of legal certainty, namely the principle within a state law that prioritizes the basis of legislation and justice in every policy of OJK implementation;

3. The principle of public interest, the principle that defends and protects the interests of consumers and society and promotes the general welfare; 
4. The principle of openness, the principle that opens itself to the right of the people to obtain correct, honest and non-discriminatory information about the operation of OJK, while maintaining the protection of personal and group rights, and state secrets, including secrets as stipulated in law -invitation;

5. The principle of professionalism, namely the principle of prioritizing expertise in the performance of OJK duties and authorities, in keeping with the code of ethics and the provisions of legislation;

6. The principle of integrity, the principle that holds to moral values in every action and decision taken in the implementation of OJK; and

7. Principle of accountability, namely the principle that determines that every activity and the end result of any OJK activities must be accountable to the public.

\subsubsection{Case study}

OJK bankruptcy application against PT Asuransi Syariah Mubarakah initially requested bankruptcy to the Central Jakarta Commercial Court with Case No. 08 / PDT-SUS-PAILIT / 2016 / PN.NIAGA.Jkt.Pst which in its decision the Panel of Judges rejected the OJK lawsuit by reason applications are considered blurred and unclear. There is a misrepresentation of the business license on behalf of PT Asuransi Syariah Mubarakah, PT Asuransi Syariah Mubarakah is declared as an insurance company that obtains a business license based on Decree of Minister of Finance no. Kep-409 / KM.017 / 1996 on June 11, 1996 was supposed to be PT Asuransi Syariah Mubarakah obtained a business license based on the Decree of the Minister of Finance No.Kep-579 / KMK.017 / 1997 in November 1997.

Subsequently, OJK has chosen to file a petition for bankruptcy with no. 36 / Pdt.Sus / Bankrupt / 2016 / PN.Niaga.Jkt.Pst. which in its verdict the Panel of Judges granted the bankruptcy request from OJK and stated that PT Asuransi Syariah Mubarakah Bankrupt with all its legal consequences. Unsatisfied with the decision of the Commercial Court, PT Asuransi Syariah Mubarakah filed an appeal in case No. 1016 K / Pdt.Sus-Bankrupt / 2016 which in its verdict the Panel of Judges rejected the application of cassation from the Cassation Appellant in this case filed by PT Asuransi Syariah Mubarakah.

Bankruptcy petition filed by OJK against PT Asuransi Syariah Mubarakah originated from a request from one of PT Asuransi Syariah Mubarakah customers namely Perum Jamkrindo which gave a letter to OJK to show a legal relationship between Perum 
Jamkrindo and PT Asuransi Syariah Mubarakah. In his letter explained that PT Asuransi Syariah Mubarakah has not paid the settlement of claim payment against Perum Jamkrindo Rp 60.884.628.596,21. Payment of claim against Perum Jamkrindo should be paid by PT Asuransi Syariah Mubarakah before December 31, 2015.

Other customers who have not paid the claim payment by PT Asuransi Syariah Mubarakah other than Perum Jamkrindo include: PT Bank BJB, PT BNI Syariah, PD BPR Bank Magelang, BPRS Mandiri Mitra Sukses, PT Medicom Prima, Pro Medika Hospital, RSIA Anugerah Bunda Khatulistiwa, H. Asrul Tanjung, Bro. Beautiful Diyani, Br. Syafrida Anof.

\subsubsection{The capacity of OJK in insolvency cases}

Judging from one of the principles contained in the general explanation of OJK Law, the principle of public interest is explained that in carrying out its duties and authority OJK must defend and protect the interests of consumers and society and promote general welfare. If it is related to the Bankruptcy Case of The ASM Co, Ltd, OJK has used this principle well and in accordance with the prevailing laws and regulations. This can be seen from the article 50 of OJK Law which states that the application of bankruptcy statement to the Takaful company is submitted by OJK in accordance with the prevailing laws and regulations. In addition to those clients whose claims have not been paid by The ASM Co, Ltd, they have exercised their right to apply for bankruptcy against The ASM Co, Ltd in accordance with the laws and regulations by submitting a petition to the Financial Services Authority to file an application for bankruptcy to the Commercial Court. This does not necessarily cause OJK to remain authorized to apply for bankruptcy against The ASM Co, Ltd this is because basically the concept of agreement used by Thr ASM Co, Ltd is different from conventional insurance company that acts as a risk bearer of the customer which the customer pays the premium to the company. In sharia insurance the company only acts as a fund manager and the participants have agreed to provide tabarru funds to be managed by sharia insurance companies. Thus the funds that have been given to the company can not be interpreted as a debt that can be used as the basis of bankruptcy, OJK authority to file a bankruptcy request can not be done.

\subsection{Arguments of authority}




\subsubsection{The authority of commercial court to terminate bankruptcy of Sharia insurance company}

Based on Article 300 of The Law on Bankruptcy and Suspension of Payment Obligationson (UUK-PKPU) it is stated that the Commercial Court has the authority to examine and decide cases of Bankruptcy and Suspension of Payment Obligations. Although it has been determined that the commercial court has the authority to adjudicate bankruptcy proceedings but it does not necessarily make the commercial court prosecute all bankruptcy cases. One of the things that the commercial courts have to consider in judging a bankruptcy case is the legal subject to be bankrupted (debtor). According to Article 1 point (3) of the UUK-PKPU, "Debtor is a person who has debt due to agreement or law whose repayment can be billed in court." The matter to be reviewed in the jurisdiction of the commercial court in adjudicating the bankruptcy case is the debtor debt problem. This is because in bankrupting the debtor, the debtor must have a debt because of the agreement or law that repayment can be billed in court

If it is associated with The ASM Co, Ltd bankruptcy case then The ASM Co, Ltd is not a debtor defined by UUK-PKPU. This is because The ASM Co, Ltdis an insurance company based on sharia principles in running its business using the concept of takaful to enter into agreements with its customers. This concept is the concept of mutual help where a group of people help each other, guarantee each other, and work together, with each way out of tabarru funds. Departing from this concept that distinguishes the overall concept of conventional insurance with sharia insurance where sharia insurance does not recognize the transfer of risk but only recognize and use the sharing of risk that the participants bear each other risk. Unlike the case with conventional insurance which the insurer i.e. the insurance company has an obligation arising as a legal consequence of the insurance agreement made with the insured is to pay insurance money in case of an insured event However, in insurance sharia, the insurance company is not as the insurer, but as the holder of the mandate which collects Tabarru 'funds intended to help help among the affected participants so that in this case the buyer does not buy the policy, nor the transfer of ownership of funds, but the pooling of funds.

Sharia insurance company can't be a debtor in the bankruptcy process by the commercial court because the concept of takaful which is the basis of the agreement between the customer and the company can not be said as debt. This can be seen from the Takaful agreement that uses the concept of sharing of risk that the participants bear each other risk by way of each spent tabarru funds managed by sharia insurance companies. It is also supported by some basic principles embodied in entering into a 
Takaful insurance agreement that is to help, cooperation, and willingness. Participants in entering into an agreement with the Takaful company from the beginning do intend to work together with each other to help each other voluntarily by using tabarru funds. Therefore, it can not be said that the tabarru funds provided by customers to sharia insurance companies are debts that can be used as the basis of bankruptcy because the tabarru funds are not intended by customers to pay a premium to be reimbursed by the insurance company as done by conventional insurance companies. Thus it can not be a Takaful company to be a debtor in the case of bankruptcy if the creditor considered in bankruptcy is the customer or the participants. In the definition of debtors in UUKPKPU has also been mentioned that the debt should be able to be billed in court. It can not be fulfilled because basically the claim from the customer to The ASM Co, Ltd is basically not a debt, if basically it is not a debt then it resulted in not allowing the debt to be billed in court.

\subsubsection{The relevance of the authority of religious court to solve the insol- vency of Sharia insurance company case}

The Sharia Mubarakah Insurance Company was initially terminated for bankruptcy by the Central Jakarta Commercial Court in Case Number 36 / Pdt.Sus / Bankruptcy / 2016 / PN.Niaga.Jkt.Pst. This happens because the customers of the Shariah Mubarakah Insurance Company apply to the Financial Services Authority (OJK) to bankrupt the Sharia Mubarakah Insurance Company because the Company does not pay its customers' claims. If viewed from the side of Islamic Economic Law is basically Mubarakah Sharia Insurance Company which is an Insurance Company based on sharia principles only serves as collectors and managers of funds from customers. This means that the ownership of the funds is not in the Insurance Company but remains with the customer, unlike conventional Insurance companies that after the customer pays the premium, the premium proceeds belong to the Insurance Company. Similarly, in terms of legal relationships that occur between the Insurance Company and its customers is the relationship of business cooperation is not a debt payable as the concept of legal relationship contained in conventional insurance. So from both sides it is not appropriate if the Insurance Company Sharia to bankrupt. The decision on insolvency of Sharia Insurance Company Mubarakah was upheld by Decision of Cassation in the case Number $1016 \mathrm{~K} /$ Pdt.Sus-Bankrupt / 2016. In the termination of the case of insolvency of Sharia Insurance Company Mubarakah according to the author of the Panel of Judges less attention to the principles of sharia existing in an insurance company. This is evident from the verdict 
that only looks at the principle of bankruptcy contained in Article 2 of the Bankruptcy Act (Law No. 37 of 2004). Therefore it needs to be viewed from the perspective of Islamic economic law regarding the legal basis of insolvency of Shariah Insurance Company Mubarakah by the panel of judges.

Bankruptcy is a condition in which the debtor is unable to repay the debts of his creditors who have matured and can be billed and the debtor is not paying off at least one such debt. Takaful company is an insurance company based on sharia principles. The concept of sharia insurance agreement is based on the concept of helping to help among the customers, which means the concept of Takaful agreement does not recognize the debts of receivable between the customer and the company. In the case Number 1016 K / Pdt.Sus-Bankrupt / 2016 the judge decides bankruptcy of The ASM Co, Ltd because it is considered has complied with article 2 of the Law of Bankruptcy and Suspension of Debt Payment Obligation (UUK-PKPU) but the judge has not seen thoroughly the concept of sharia insurance agreement mubarakah which in practice the concept of sharia insurance agreement is very different from the concept of conventional insurance agreement. In this case the authors disagree with the decision of the judge to break the insolvency of The ASM Co. Ltd because the concept of insurance agreement on The ASM Co, Ltd is not debt-accounts between customers with the company but the concept of helping between customers

When it is viewed from the authority of Religious Courts, pursuant to Article 49 of Law no. 3 of 2006 on Amendment to Law no. Law No. 7 of 1989 on Religious Courts ("Law 3/2006"), which is the authority of a religious court is the first case among the people of Islam, one of which is in the field of Islamic economics. Thus, the right to judge cases between customers and Islamic insurance companies is the authority of Religious Court. If we see the authority of OJK in requesting the insolvency statement of sharia insurance company, according to Article 50 of OJK Law has been said that to be apply for bankruptcy law on Insurance company, that statement include of a sharia insurance company. Then the authority is indeed being given to OJK. However, because in case of Sharia Insurance Company Mubarakah (The ASM Co, Ltd) is specifically become a debitor of is its client whose concept used in Takaful, then the authority is no longer under OJK.

The ASM Co, Ltd is not a debtor defined by UUK-PKPU. This is because The ASM Co. Ltd is an insurance company based on sharia principles in running its business using the concept of takaful to enter into agreements with its customers. This concept is the concept of mutual help where a group of people help each other, guarantee each other, and work together, with each way out of tabarru funds. Departing from this concept 
that distinguishes the overall concept of conventional insurance with sharia insurance where sharia insurance does not recognize the transfer of risk but only recognize and use the sharing of risk that the participants bear each other risk. Unlike the case with conventional insurance which the insurer ie the insurance company has an obligation arising as a legal consequence of the insurance agreement made with the insured is to pay insurance money in case of an insured event. However, in insurance sharia, the insurance company is not as the insurer, but as the holder of the mandate which collects Tabarru 'funds intended to help among the affected participants so that in this case the buyer does not buy the polic, nor the transfer of ownership of funds, but the pooling of funds. With this concest there is no constraction of debt. As the result, if there is any insolvency then should be put into the authority of Religious Court first to settle the dispute before executing the bankcruptcy law.

\section{Conclusion}

Fundamental Difference of Bankruptcy Cases in Shariah Insurance from Convensional insurance on the operational side and the contract basis (akad) it. In this case, Readiness of Religious court become necessary in responding to insurance Bankruptcy Case. It is also necessary to clarify the position of the Bankruptcy Case (Taflis) within the authority of the Religious Courts, along with the consequences of the things that need to be prepared, namely from the regulation and supporting institutions of insolvent bankruptcy, such as the Curator and Supervisory Judge.

For the recomendation:

1. It is necessary to regulate the clarity of the position of the Bankruptcy Case (Taflis) within the authority of the Religious Courts.

2. That in order to have legal certainty in the field of Bankruptcy Law it is better for law makers to provide a clearer and more detailed understanding of the terms of debt that can be used as the basis of bankruptcy for the debtor because basically every bankruptcy must be based on the existence of debt.

3. That the OJK's duties and authorities can work properly, especially in the authority to request a bankruptcy statement against the debtor, (especially in the case of Insurance), OJK shall further examine the basic principles used by a company in running so as not to harm the debtor. 


\section{References}

[1] Law No. 7 of 1989 jo. Law No. 3 of 2006 regarding Religious Court

[2] Insurance, on the concept of sharia accessed from http://www.asuransinomor1.com/ asuransi-syariah May 23, 2018

[3] Ali, Hasan, Asuransi dalam Perspektif Hukum Islam, Suatu Tinjauan Analisis Historis, Teoritis, dan Praktis, cet. 1, (Jakarta: Prenalda Media, 2004), p 103

[4] Ma'shum, Ali, dan Zainal Abidin Munawwit, Al-Munawwir; Kamus Arab-Indonesia, (Yogyakarta: Pustaka Progresif,1997), p. 77.

[5] Sula, Muhammad Syakir, Asuransi Syariah (Life and General) Konsep dan Sistem Operasional, Cet. 1, (Jakarta: Gema Insani, 2004), p 303.

[6] Mohd, Ma'sum Billah, Principle and Practices of Takaful and Insurance Compared, (Kuala Lumpur: IIUM Press, 2001) p 17.

[7] Imantoro, Bayu. (2009). Analisis tanggung jawab agen pemasaran produk asuransi prudential syariah terhadap PT prudential life assurance Indonesia dan pengguna produk prudential syariah. Undergraduate Thesis, University of Indonesia. p 18.

[8] Muhammad Syakir Sula, 2004, p 33.

[9] Syahdeini, Sutan Remy, Hukum Kepailitan Memahami Undang-Undang No. 37 Tahun 2004 Tentang Kepailitan Cet.V, ( Jakarta: Pustaka Utama Grafiti, 2012) p 53.

[10] Kornelius Simanjuntak, et.al., Hukum Asuransi, cet.1, (Depok: Djokosoetono Research Center FHUI, 2011), p 10.

[11] Sula, Muhammad Syakir, Asuransi Syariah (Life and General) Konsep dan Sistem Operasional, Cet. 1. Jakarta: Gema Insani, 2004, p 33.

[12] Subhan, Hadi, Hukum Kepailitan Prinsip, Norma, dan Praktik di Peradilan, (Jakarta: Kencana, 2008), p 1.

[13] Projodikoro, Wirjono, Hukum Asuransi di Indonesia, ( Jakarta: Intermasa, 1987), p 1.

[14] Imantoro, Bayu. (2009). Analisis tanggung jawab agen pemasaran produk asuransi prudential syariah terhadap PT prudential life assurance Indonesia dan pengguna produk prudential syariah. Undergraduate Thesis, University of Indonesia. p 18. 